\title{
Patogenitas Cendawan Entomopatogen Nomuraea rileyi (Farl.) Sams. terhadap Hama Spodoptera exigua Hübner (Lepidoptera: Noctuidae)
}

\author{
TRIZELIA \\ Jurusan Hama dan Penyakit Tumbuhan Fakultas Pertanian Universitas Andalas \\ (diterima Mei 2008, disetujui Agustus 2008)
}

\begin{abstract}
Pathogenecity of Entomopatogenecity of Nomuraea rileyi (Farl.) Sams to Spodoptera exigua Hübner (Lepidoptera: Noctuidae). The purpose of this research is to study the pathogenicity of Nomuraea rileyi (Farl.) Sams. to eggs and larvae of Spodoptera exigua Hübner (Lepidoptera: Noctuidae). The fungi were isolated from insect cadaver of S. exigua. Egg clusters and several instar larvae with different conidial concentrations $\left(10^{6}-10^{9}\right.$ conidia/ml) were used in the experiment. The results of experiment showed that there was no effect of all concentrations of fungi on egg mortality. Mortality of $S$. exigua larvae was dependent on the instar and conidial concentration. Generally with increasing conidial concentrations, the mortality were also increasing.
\end{abstract}

KEY WORDS: Nomuraea rileyi,Pathogenicity, Spodoptera exigua

\section{PENDAHULUAN}

Di Indonesia, Spodoptera exigua Hubner merupakan salah satu hama yang paling merusak pada tanaman keluarga bawang-bawangan seperti bawang merah dan bawang daun (Kalshoven 1981). Hama S. exigua dapat menyerang tanaman bawang sejak awal pertumbuhan dan mengakibatkan kehilangan hasil yang tidak sedikit. Larva menimbulkan kerusakan dengan cara memakan daun tanaman. Menurut Sastrosiswojo (1994), kehilangan hasil akibat serangan larva $S$. exigua dapat mencapai 57\%. Serangan berat dapat menyebabkan kehilangan hasil sampai $100 \%$, karena daun yang ada habis dimakan oleh larva sehingga kegagalan panen tidak bisa dihindari. Serangan berat ini biasanya terjadi pada musim kemarau yang mengakibatkan produksi tanaman menurun (Shepard et al. 1997; Utami 1997).

Sampai saat ini untuk mengendalikan hama $S$. exigua para petani masih mengandalkan insektisida kimia karena mereka menganggap insektisida merupakan jaminan untuk keberhasilan usaha taninya. Aplikasi penggunaan insektisida kimia dilakukan dalam selang waktu 2-3 hari sekali dan bahan kimia yang 
disemprotkan merupakan campuran dari berbagai jenis insektisida (Utami 1997). Hal ini sangat disayangkan mengingat Indonesia sedang menuju era pembangunan pertanian yang berwawasan lingkungan, sehingga insektisida kimia sintetis harus digunakan seminimal mungkin.

Salah satu cara pengendalian hama S. exigua yang ramah lingkungan adalah dengan menggunakan musuh alami serangga hama baik berupa predator, parasitoid maupun patogen. Pengendalian serangga hama dengan patogen merupakan suatu proses pemanfaatan patogen baik yang sudah ada di ekosistem setempat maupun dengan memasukkannya ke dalam suatu ekosistem dari luar melalui teknik inokulasi dan inundasi dan diharapkan tidak menimbulkan goncangan dan reaksi balik dari ekosistem yang merugikan kita. Salah satu jenis patogen serangga yang banyak terdapat di alam dan dapat digunakan untuk pengendalian serangga hama secara hayati adalah cendawan entomopatogen Nomuraea rileyi (Farl.) Sams.(Hyphomycetes).

Di Indonesia potensi patogenik $N$. rileyi terhadap serangga hama belum begitu banyak ditelaah dan diteliti. Rieswanto (1998) melaporkan bahwa cendawan $N$. rileyi dapat mematikan larva Helicoverpa armigera. Berdasarkan hasil survei dan inventarisasi yang dilakukan oleh Shepard et al. (1997). sejak tahun
1992-1997 pada pertanaman bawang daun menunjukkan bahwa cendawan entomopatogen $N$. rileyi ini merupakan patogen serangga yang paling sering ditemukan dan tingkat infeksi umumnya lebih tinggi pada daerah dataran tinggi yang lembab.

Menurut Suryawan dan Carner (1993). N. rileyi merupakan salah satu cendawan patogen yang ditemukan pada hama-hama penting pada tanaman palawija dan sayuran seperti Spodoptera litura, $S$. exigua, Helicoverpa armigera, Chrysodeixis chalcites dan Crocidolomia binotalis. Pada tanaman kedelai, mortalitas larva yang disebabkan oleh $N$. rileyi relatif tinggi, dapat mencapai $100 \%$. Keadaan demikian sangat dimungkinkan karena kondisi iklim di Indonesia sangat mendukung pertumbuhan dan perkembangan cendawan entomopatogen ini. Berdasarkan survei pendahuluan ditemukan adanya larva $S$. exigua yang terinfeksi oleh cendawan $N$. rileyi, namun potensinya dalam mengendalikan hama ini belum banyak diteliti.

Berdasarkan hal tersebut di atas perlu dilakukan serangkaian penelitian terutama dalam hal penentuan konsentrasi konidia yang tepat dalam mematikan serangga dan kemampuan cendawan untuk bertahan di lapangan karena kedua factor tersebut menentukan efikasi dan persistensi agensia dalam pengendalian. 
Tujuan dari penelitian ini adalah untuk : 1) mempelajari patogenesitas cendawan $N$. rileyi terhadap telur $S$. exigua, 2) menentukan konsentrasi konidia cendawan yang efektif dalam mematikan larva S. exigua.

\section{BAHAN DAN METODE}

Penelitian ini dilaksanakan di Laboratorium Jurusan Hama dan Penyakit Tumbuhan Fakultas Pertanian Universitas Andalas Padang

\section{Koleksi dan Perbanyakan Cendawan $N$. rileyi}

Cendawan $N$ rileyi yang digunakan dalam penelitian ini dikoleksi langsung dari serangga $S$. exigua yang terinfeksi di lapangan. Cendawan ditumbuhkan pada medium Sabauraud maltose agar dengan 2\% yeast extract (SMAY). Propagul cendawan yang diisolasi adalah konidia cendawan yang tumbuh di bagian luar tubuh larva. Identifikasi cendawan dilakukan secara makroskopis dan miktoskopis.

Setelah didapatkan isolat $N$. rileyi murni, lalu dilakukan pembiakan awal dalam cawan petri yang berisi $15 \mathrm{ml}$ media SMAY. Biakan diinkubasikan pada suhu $20-25^{\circ} \mathrm{C}$ selama 15 hari. Untuk mempertahankan virulensi dari isolat yang diuji, isolat diinokulasikan kembali pada larva $S$. exigua. Dari larva S. exigua yang terinfeksi diisolasi kembali dan dimurnikan pada media SMAY.

\section{Penyediaan Tanaman Bawang Daun}

Tanaman bawang daun yang digunakan sebagai pakan larva $S$. exigua di tanaman dalam polibag. Bibit tanaman bawang daun diperoleh dari petani dan ditanam dalam polibag yang telah berisi campuran tanah dan pupuk kandang. Tanaman dipupuk dengan pupuk NPK (setara $200 \mathrm{~kg} / \mathrm{ha}$ Urea, $200 \mathrm{~kg} / \mathrm{ha}$ TSP, $100 \mathrm{~kg} / \mathrm{ha} \mathrm{KCl}$ ) dan tanaman tidak disemprot dengan pestisida.

\section{Perbanyakan Larva S. exigua}

Larva $S$. exigua dikumpulkan dari pertanaman bawang daun di lapangan dan kemudian dipelihara dalam kotak plastik dan diberi makanan berupa daun bawang yang masih segar. Makanan larva diganti setelah habis atau sudah tidak segar.

Larva-larva tersebut dipelihara sampai membentuk pupa dan imago. Selanjutnya imago-imago yang diperoleh dimasukkan ke dalam kurungan serangga yang telah berisi tanaman bawang daun sebagai tempat peletakkan telur. Sebagai makanan imago digunakan madu dengan konsentrasi $10 \%$. Kelompok telur yang diletakkan dipindahkan ke kotak plastik lain dan dipelihara sampai menetas.

\section{Uji Patogenisitas $N$. rileyi terhadap}

Telur $S$. exigua

Cendawan $N$. rileyi ditumbuhkan pada media SMAY pada suhu $25^{\circ} \mathrm{C}$ selama 15 hari. Suspensi konidia 
disiapkan dengan cara penambahan akuades steril dan Triton X 100 ke dalam biakan dan konsentrasi konidia dihitung dengan menggunakan hemasitometer. Konsentrasi konidia cendawan yang digunakan untuk pengujian kerentanan stadia telur terhadap infeksi $N$. rileyi adalah $10^{9}$, $10^{8}, 10^{7}$, dan $10^{6}$ konidia $/ \mathrm{ml}$.

Untuk masing-masing perlakuan, satu kelompok telur $S$. exigua yang telah diletakkan pada daun bawang daun dan berumur satu hari disemprot dengan suspensi konidia, kemudian dipindahkan ke dalam cawan petri yang telah dialas dengan kertas saring lembab. Kelompok telur yang telah diperlakukan dipelihara sampai menetas. Percobaan diulang empat kali dan hal-hal yang diamati adalah perkembangan telur, persentase telur menetas, dan persentase telur yang tidak menetas

Percobaan disusun dalam rancangan acak lengkap (RAL) dengan lima taraf perlakuan (konsentrasi konidia) dan tiga ulangan. Data hasil percobaan dianalisis dengan sidik ragam dan dilanjutkan dengan pengujian nilai tengah menggunakan uji jarak berganda Duncan (DMRT) pada taraf nyata lima persen.

\section{Uji Patogenisitas $N$. rileyi terhadap}

\section{Larva $S$. exigua}

Pengujian dilakukan terhadap semua instar larva $S$. exigua. Konsentrasi konidia cendawan yang digunakan sama dengan percobaan pengujian kerentanan stadia telur. Aplikasi cendawan dilakukan dengan cara meneteskan suspensi konidia pada bagian dorsal tubuh larva. Kemudian larva diberi makan daun bawang segar. Percobaan diulang empat kali dan setiap satuan percobaan terdiri dari 20 ekor larva. Mortalitas larva diamati setiap hari hingga tujuh hari setelah aplikasi $N$. rileyi. Untuk menentukan konsentrasi letal $50 \%\left(\mathrm{LC}_{50}\right)$ masingmasing instar digunakan analisis probit dan regresi linear.

\section{HASIL DAN PEMBAHASAN}

\section{Uji Patogenisitas $N$. rileyi terhadap Telur S. exigua}

Hasil uji patogenisitas $N$. rileyi terhadap telur $S$. exigua menunjukkan bahwa cendawan $N$. rileyi tidak mempengaruhi perkembangan telur $S$. exigua. Analisis statistik menunjukkan bahwa tidak ada perbedaan yang nyata antara telur $S$. exigua yang diaplikasi dengan suspensi konidia $N$. rileyi dengan kontrol $(\mathrm{F}=2.15 ; \mathrm{db}=4,10$; $\mathrm{P}<0.1484$ ). Hampir $100 \%$ telur $S$. exigua masih mampu menetas walaupun telah diberi perlakuan dengan suspensi konidia $N$. rileyi (Tabel 1). Semua konsentrasi konidia cendawan yang diuji tidak bisa menginfeksi telur S. exigua dan telur menetas secara normal. Berdasarkan pengamatan makroskopis, telur $S$. exigua yang telah diaplikasi dengan $N$. 
Tabel 1. Rata-rata persentase telur S. exigua menetas dan tidak menetas setelah aplikasi berbagai konsentrasi konidia $N$. rileyi

\begin{tabular}{lcc}
\hline $\begin{array}{l}\text { Konsentrasi } \\
\text { (konidia/ml) }\end{array}$ & Telur menetas \pm SD $(\%)$ & Telur tidak menetas \pm SD $(\%)$ \\
\hline $10^{9}$ & $89.85 \pm 9.15 \mathrm{a}$ & $10.15 \pm 9.15 \mathrm{a}$ \\
$10^{8}$ & $96.63 \pm 3.23 \mathrm{a}$ & $3.37 \pm 3.23 \mathrm{a}$ \\
$10^{7}$ & $100.00 \pm 0.00 \mathrm{a}$ & $0.00 \pm 0.00 \mathrm{a}$ \\
$10^{6}$ & $100.00 \pm 0.00 \mathrm{a}$ & $0.00 \pm 0.00 \mathrm{a}$ \\
Kontrol & $93.58 \pm 6.18 \mathrm{a}$ & $6.42 \pm 5.18 \mathrm{a}$ \\
\hline
\end{tabular}

Angka yang diikuti huruf yang sama pada kolom yang sama tidak berbeda nyata menurut uji Duncan (DMRT) pada taraf nyata 5\%

rileyi tidak memperlihatkan adanya gejala infeksi $N$. rileyi. Hal ini menunjukkan bahwa $N$. rileyi tidak dapat menginfeksi telur $S$. exigua. Tidak terjadinya infeksi pada telur mungkin disebabkan oleh sifat kulit telur $S$. exigua yang mempunyai lapisan tertentu yang diduga menghalangi tabung kecambah konidia menembus ke bagian dalam telur. Hasil penelitian Trizelia et al. (2007). juga menunjukkan bahwa tidak ada pengaruh aplikasi isolat Beauveria bassiana terhadap mortalitas telur Crocidolomia pavonana. James et al. (2003). mengemukakan bahwa lapisan lilin pada serangga dapat menghambat perkecambahan konidia cendawan entomopatogen.

Hasil penelitian ini berbeda dengan hasil penelitian yang dilaporkan oleh Prayogo (2004) yang melaporkan bahwa lima jenis cendawan entomopatogen, yaitu Nomuraea rileyi (Farl.) Sams, Verticillium lecanii (Zimmermann), Metarhizium anisopliae (Metschn.) Sorokin,
Beauveria bassiana, dan Paecilomyces fumosoroseus (Wize) Brown and Smith) mampu menginfeksi telur Riptortus linearis (L.) (Hemiptera: Alydidae) sehingga persentase telur yang menetas membentuk nimfa sangat rendah.

\section{Uji Patogenisitas $N$. rileyi terhadap Larva $S$. exigua}

Hasil pengujian laboratorium berbagai konsentrasi konidia $N$. rileyi terhadap berbagai instar larva $S$. exigua menunjukkan bahwa perbedaan konsentrasi konidia dan instar larva menghasilkan respon tingkat kematian yang berbeda. Untuk semua instar larva, semakin tinggi konsentrasi konidia maka mortalitas serangga juga semakin tinggi. (Tabel 2).

Untuk keseluruhan instar yang diuji, mortalitas larva $S$. exigua meningkat dengan meningkatnya konsentrasi konidia $N$. rileyi. Hal ini berarti bahwa semakin tinggi jumlah konidia, maka peluang hama sasaran terinfeksi atau mati semakin besar. Roberts \& Yendol (1971). 
mengemukakan bahwa salah satu faktor untuk bisa terjadinya infeksi Tabel 2. Rata-rata mortalitas berbagai instar larva $S$. exigua setelah aplikasi berbagai konsentrasi konidia $N$. rileyi

\begin{tabular}{lccccc}
\hline \hline Instar & \multicolumn{5}{c}{ Konsentrasi $N$. rileyi } \\
& 0 & $10^{6}$ & $10^{7}$ & $10^{8}$ & $10^{9}$ \\
\hline I & $2,50 \mathrm{c}$ & $83,75 \mathrm{~b}$ & $97,50 \mathrm{a}$ & $100,00 \mathrm{a}$ & $100,00 \mathrm{a}$ \\
II & $3,75 \mathrm{~d}$ & $70,00 \mathrm{c}$ & $85,25 \mathrm{~b}$ & $95,00 \mathrm{a}$ & $100,00 \mathrm{a}$ \\
III & $2,50 \mathrm{~d}$ & $22,50 \mathrm{c}$ & $32,50 \mathrm{~b}$ & $40,00 \mathrm{~b}$ & $53,75 \mathrm{a}$ \\
IV & $2,50 \mathrm{~d}$ & $23,75 \mathrm{c}$ & $31,25 \mathrm{bc}$ & $35,25 \mathrm{~b}$ & $55,25 \mathrm{a}$ \\
\hline
\end{tabular}

Angka yang diikuti huruf yang sama pada baris yang sama tidak berbeda nyata menurut uji Duncan (DMRT) pada taraf nyata $5 \%$

Tabel 3. Nilai $\mathrm{LC}_{50} N$. rileyi pada berbagai instar larva $S$. exigua

\begin{tabular}{lc}
\hline \hline Instar & $\mathrm{LC}_{50}(\mathrm{SK} 95 \%)(\mathrm{konidia} / \mathrm{ml})$ \\
\hline I & $1,22 \times 10^{6}\left(3,13 \times 10^{4}-3,68 \times 10^{6}\right)$ \\
II & $1,95 \times 10^{6}\left(2,39 \times 10^{5}-5,86 \times 10^{6}\right)$ \\
III & $1,21 \times 10^{8}\left(4,70 \times 10^{7}-2,63 \times 10^{8}\right)$ \\
IV & $7,12 \times 10^{9}\left(1,80 \times 10^{9}-1,43 \times 10^{11}\right)$ \\
\hline
\end{tabular}

cendawan entomopatogen pada berkaitan dengan tingkat ketahanan serangga adalah jumlah inokulum.

serangga. Pada umumnya semakin

Hasil penelitian ini sejalan dengan tinggi tingkat ketahanan serangga hasil penelitian peneliti sebelumnya yang menunjukkan adanya korelasi positif antara konsentrasi konidia $N$. rileyi dengan mortalitas serangga uji, yaitu semakin tinggi konsentrasi konidia maka mortalitas serangga juga semakin tinggi (Rieswanto 1998).

Hasil perhitungan nilai $\mathrm{LC}_{50}$ menunjukkan bahwa nilai LC $_{50}$ larva instar I lebih rendah daripada nilai $\mathrm{LC}_{50}$ larva instar II, III dan IV (Tabel 3). Hal ini berarti bahwa larva instar I lebih rentan bila dibandingkan dengan larva instar II, III dan IV. Semakin muda tingkat instar larva $S$. exigua akan semakin rentan terinfeksi oleh $N$. rileyi. Adanya perbedaan jumlah terhadap infeksi patogen, maka semakin tinggi konsentrasi konidia yang dibutuhkan untuk mematikannya.

Salah satu faktor yang berperan penting dalam keberhasilan penggunaan cendawan entomopatogen adalah stadia perkembangan serangga. Tidak seluruh stadia dalam perkembangan serangga rentan terhadap infeksi cendawan (Inglis et al. 2001). Hasil penelitian Rieswanto (1998). juga menunjukkan bahwa kerentanan larva $H$. armigera terhadap $N$. rileyi berhubungan erat dengan instar larva. Larva $H$. armigera instar I lebih rentan dibandingkan dengan larva instar II dan III. Kerentanan konidia yang dibutuhkan untuk larva semakin berkurang dengan mematikan larva $S$. exigua sangat bertambahnya tingkat instar larva. 
Nilai LC $_{50}$ larva instar I, II dan III berturut-turut adalah $9.55 \times 10^{6}, 3.94 \mathrm{x}$ $10^{7}, 1.90 \times 10^{8}$ konidia $/ \mathrm{ml}$.

\section{KESIMPULAN}

Hasil penelitian menunjukkan bahwa cendawan entomopatogen $N$. rileyi tidak bisa menginfeksi telur $S$. exigua dan telur menetas secara normal. Patogenisitas $N$. rileyi terhadap larva $S$. exigua sangat dipengaruhi oleh instar larva dan konsentrasi konidia. Semakin muda tingkat instar larva $S$. exigua akan semakin rentan terinfeksi oleh $N$. rileyi. Larva instar I lebih rentan bila dibandingkan dengan larva instar II, III dan IV. Semakin tinggi konsentrasi konidia, semakin tinggi mortalitas larva S. exigua.

\section{UCAPAN TERIMA KASIH}

Penulis mengucapkan terima kasih kepada Direktorat Pembinaan Penelitian dan Pengabdian kepada Masyarakat, Direktorat Jenderal Pendidikan Tinggi Dengan Nomor Kontrak : 018/SPPP/PP/DP3M/V/2005 yang telah membantu pendanaan penelitian ini.

\section{DAFTAR PUSTAKA}

Inglis GD, Goettel MS, Butt TM, Strasser H. 2001. Use of hyphomycetous fungi for managing insect pests. Di dalam : Butt TM, Jackson CW dan Magan N. Editor. Fungi as Biocontrol Agents,
Progress, Problems and Potential. London : CABI Publishing. hlm. 23-69.

James RR, Buckner JS, Freeman TP. 2003. Cuticular lipids and silverleaf whitefly stage affect conidial germination of Beauveria bassiana and Paecilomyces fumosoroseus. $J$ Invertebr Pathol 84:6774.

Kalshoven LGE. 1981. The Pest of Crops in Indonesia. Lann PA van der, penerjemah. Jakarta: Ichtiar Baru-Van Hoeve.

Prayogo Y. 2004. Keefektifan lima jenis cendawan entomopatogen untuk mengendalikan hama pengisap polong kedelai. Riptortus linearis L. (Hemiptera: Alydidae) dan dampaknya terhadap predator Oxyopes javanus (Araneidae: Oxyopidae). [Tesis]. Bogor: Institut Pertanian Bogor.

Rieswanto SWA. RD. 1998. Perbanyakan inokulum Nomuraea rileyi (Farl.) Sams. dan virulensinya terhadap ulat perusak buah Helicoverpa armigera (Hbn.) (Lepidoptera:Noctuidae). Tesis. Program Pascasarjana IPB Bogor. $39 \mathrm{hlm}$.

Roberts DW, Yendol WG. 1971. Use of fungi for microbial control. Di dalam: Burges HD dan Hussey NW. editor. Microbial Control of Insects and Mites. London. New York: Academic Press. hlm 125-149. 
Sastrosiswojo S. 1994. Development and implementation of Integrated Pest management in Some Vegetable Crops. Lembang Horticultural Research Institute. $22 \mathrm{hlm}$.

Shepard M et al., 1997. Prospect for IPM in secondary food crops. Makalah disajikan pada Kongres V dan Simposium Entomologi, Perhimpunan Entomologi Indonesia, Bandung, 24-26 Juni 1997. Bandung. $31 \mathrm{hlm}$.

Suryawan IBG dan Carner GR. 1993. Cendawan patogen dari serangga hama pada tanaman palawija dan sayuran. Di dalam: Simposium Patologi
Serangga I. Prosiding Makalah Simposium Patologi Serangga I. Yogyakarta. 1213 Oktober 1993. Yogyakarta. hlm. 288-295.

Trizelia, Teguh Santoso, Soemartono Sosromarsono, Aunu Rauf dan Lisdar I Sudirman. 2007. Patogenisitas Jamur Entomopatogen Beauveria bassiana (Deuteromycotina: Hyphomycetes) terhadap telur Crocidolomia pavonana (Lepidoptera: Pyralidae). Agrin 11(1):52-59.

Utami KP. 1997. Virus SENPV atasi ulat grayak pada bawang merah. Trubus 337-TH XXVIII-Desember :74-76. 